ENGLISH BIOGRAPHY IN THE SEVENTEENTH CENTURY:

A CRITICAL SURVEY 
This page intentionally left blank 


\section{English Biography in the Seventeenth Century}

A Critical Survey

ALLAN PRITCHARD

UNIVERSITY OF TORONTO PRESS

Toronto Buffalo London 


\section{www.utppublishing.com}

(C) University of Toronto Press Incorporated 2005

Toronto Buffalo London

Printed in Canada

ISBN 0-8020-3889-1

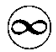

Printed on acid-free paper

\section{Library and Archives Canada Cataloguing in Publication}

Pritchard, Allan

English biography in the seventeenth century:

a critical survey / Allan Pritchard.

Includes bibliographical references and index.

ISBN 0-8020-3889-1

1. England - Biography - History and criticism. 2. Biography as a literary form. 3. English prose literature -17 th century History and criticism. I. Title.

CT34.G7P74 $2005 \quad 820.9^{\prime} 4920042^{\prime} 09032 \quad$ C2005-900428-2

University of Toronto Press acknowledges the financial assistance to its publishing program of the Canada Council for the Arts and the Ontario Arts Council.

This book has been published with the help of a grant from the Canadian Federation for the Humanities and Social Sciences, through the Aid to Scholarly

Publications Programme, using funds provided by the Social Sciences and Humanities Research Council of Canada.

University of Toronto Press acknowledges the financial support for its publishing activities of the Government of Canada through the Book Publishing Industry Development Program (BPIDP). 